\title{
Media Pembelajaran sebagai Pembawa Pesan
}

\author{
Ida Nuraini
}

ABSTRACT

\begin{abstract}
Education technology is as important as the education itself. Education technology speaks more than just supporting devices for learning. It is actually a systematic way of designing, implementing, and evaluating the total process of learning and teaching in terms of specific objective. Based on research in human learning and communication, education technology employs a combination of human and nonhuman resources to bring about more effective instruction. The main issues of education technology lie on technology capability to deliver education messages. Some factors need to be addressed: communication obstacles, kinds of media, new media research for education purposes, institutional support as well as public policy support.
\end{abstract}

Kata kunci: teknologi pendidikan, pesan, proses pembelajaran, media, lembaga

\section{Pendahuluan}

Salah satu bidang pengetahuan terapan yang diharapkan semakin banyak memberikan konstribusinya terhadap perkembangan pendidikan di tanah air kita ialah bidang Teknologi pendidikan. Kemampuan untuk memanfaatkan teknologi modern dalam upaya pengembangan pendidikan, tentu saja, sangat tergantung pada jumlah dan kemampuan para ahli dalam bidang teknologi pendidikan.

Teknologi baru akan mempunyai implikasi yang radikal terhadap proses belajar mengajar konvensional. Dalam merekonfigurasi bagaimana pengajar dan siswa mendapatkan akses ke pengetahuan dan informasi, teknologi baru menantang konsepsi konvensional mengena bahan-bahan belajar mengajar, dan metode serta pendekatan belajar mengajar (Unesco, 2002).

Dalam konteks pergeseran paradigma pembelajaran, sesungguhnya dalam dasawarsa terakhir telah terjadi perubahan dan pergeseranpergeseran penting dalam teknologi pendidikan/ pembelajaran. Suparman dalam beberapa artikel pentingnya (1999a; 1999b), misalnya mengungkapkan sejumlah perkembangan dalam teknologi pendidikan, yang mencakup adopsi berbagai sistem, teknik, dan alat meningkatkan kualitas, efektivitas dan efisiensi pembelajaran.

Salah satu penekanan pokok dalam konsep teknologi pendidikan adalah adopsi berbagai perangkat teknologi transmisi, mulai dari bentuk sederhana audio visual, hingga sampai kepada media pembelajaran multimedia yang sangat canggih dewasa ini. Perkembangan-perkembangan mutakhir yang menghasilkan "revolusi internet", "telepon seluler" dan sebagainya, jelas mengimplikasikan bahwa pembelajaran kini telah menembus batas-batas ruang dan waktu. Dengan demikian, proses pembelajaran semakin mengalami "demokratisasi" dan equity; kini setiap peserta 
didik dan orang tahu tentang "learn how to learn" dapat mengakses berbagai sumber informasi dan pengetahuan nyaris tanpa batas. Teknologi pendidikan yang benar-benar fungsional haruslah beyond teknologi pendidikan, suatu formulasi substansial yang memuat hal-hal yang lebih makro daripada sekadar hal-hal teknis mengenai desain instruksional.

Dampak globalisasi akan memengaruhi segala aspek dalam kehidupan manusia, termasuk juga dalam dunia pendidikan, khususnya dalam proses pembelajaran. Untuk itu perlu dilakukan perubahan paradigma dalam proses pembelajaran terutama tentang konsep bagaimana cara orang belajar dan bagaimana cara materi ajar itu diberikan. Menyikapi dampak globalisasi ini perlu adanya pergeseran tentang peran guru yang selama ini dianggap sebagai sau-satunya sumber belajar, atau orang yang paling tahu di sekolah berubah menjadi hanya sebagai salah satu sumber belajar. Sejalan dengan kemajuan di bidang ilmu pengetahuan dan teknologi, khususnya teknologi informasi/ pendidikan/pembelajaran, guru harus lebih berperan sebagai fasilitator dengan mengoptimalkan penggunaan sumber-sumber belajar lain, misalnya media pendidikan.

\section{Pembahasan}

\subsection{Teknologi Pendidikan}

Istilah teknologi pendidikan adalah sesuatu yang menunjuk dan berkenaan dengan mekanisme pendidikan. Pada November 1964, Skinner memberikan ceramah pada Royal Society dengan judul "The Technology of Teaching" (Skinner: 1968). Hal ini barangkali merupakan awal mula daripada teknologi pendidikan (Hamalik, 2000: 16). Skinner menggunakannya bukan dalam artian mekanistik, melainkan lebih mengacu pada pemunculan prinsip-prinsip pendidikan belajar berprograma. Prinsip-prinsip tersebut mendasari pentingnya siswa sebagai pusat proses belajar mengajar, yang merupakan perubahan proses yang berorientasi pada guru. Tanggung jawab kemajuan belajar terletak pada siswa sendiri. Perubahan inilah yang menitikberatkan munculnya disiplin ilmu teknologi pendidikan.
Teknologi pendidikan secara mendasar merupakan aplikasi dari pendekatan sistematik atau sistematic approach. Pendekatan tersebut tampak pada tiga aspek utama, yaitu: (1) spesifikasi tujuantujuan pendidikan dalam suatu pembelajaran; (2) penentuan metode-netode mengajar/belajar yang digunakan; (3) penilaian materi pelajaran sehubungan dengan tujuan yang hendak dicapai.

Pendekatan sistematik pendidikan menerima siswa sebagai proses belajar dan berkenaan dengan berbagai metode yang dapat digunakan, misalnya pengajaran individual. Dengan perkembangan teknologi informasi, metodemetode belajar mengajar masa depan akan dipengaruhi oleh teknologi baru dan perkembangan dalam elektronik mikro (Hills, 1982:45).

Ada beberapa definisi dari teknologi pendidikan yang dikemukakan oleh para ahli. Salah satunya adalah Fredpercival dan Henry Ellington(1984) yang mengemukakan definisi teknologi pendidikan sebagai berikut:

(a) The development, application, and evaluation of system, techniques, and aids to improve the process of human learning;(b) The application of scientific knowledge about learning, and the conditions of learning, to improve the effectiveness and efficiency of teaching and training....(c) A systematic way of designing, implementing, and evaluating of the total process of learning and teaching in terms of specific objective, based on research in human learning and communication, and employing a combination of human and non-human resources to bring about more effective instruction.

\subsection{Teknologi dalam Pendidikan}

Teknologi dalam pendidikan mencakup semua alat yang dapat digunakan untuk menyajikan informasi, khususnya yang berkenaan dengan pendidikan dan penilaian, seperti: televisi, laboratorium bahasa, dan berbagai media yang diproyeksikan serta komputer. Dapat dikatakan, bahwa semua yang tercakup sebagai audiovisual aids dapat digolongkan sebagai teknologi dalam pendidikan (technology in education) (Hamalik, 2000:18).

Bidang alat-alat audio-visual itu sendiri 
merupakan perpaduan antara dua hal yang berbeda tetapi saling berkaitan, yang disebut dengan perangkat keras (hardware) dan perangkat lunak (software). Perangkat keras berkenaan dengan peralatan/perlengkapan seperti OHP, proyektor slide, tape recorder, video cassette, monitor televisi, mikro komputer. Perangkat lunak berkaitan dengan berbagai macam hal yang digunakan dalam hubungannya dengan peralatan tadi, seperti: transparansi, slide, audiotape, rekaman video, dan program komputer.

Teknologi dalam pendidikan merupakan suatu aspek yang sangat penting dari teknologi pendidikan, terutama berkenaan dengan penggunaan unit-unit audiovisual aids. Dengan mempergunakan perangkata keras sesuai dengan perangkat lunak, maka efisiensi dan efektivitas, serta kualitas pembelajaran dapat diperbaiki atau ditingkatkan. Hal inilah yang mendasari perkembangan teknologi dalam pendidikan dewasa ini. Perangkat keras mengandung konotasi penggunaan teknik engineering seperti optik dan elektronik, dan selanjutnya dikembangkan perangkat lunak berupa materi belajar yang serasi dan berlandaskan pada psikologi dan teori-teori belajar, yang pada gilirannya menimbulkan pemikian mengenai perlunya desain belajar mengajar, dan pada akhirnya muncul penafsiran baru yang disebut dengan teknologi pendidikan.

\subsection{Hakikat Media Pendidikan/ Pembelajaran}

Media pembelajaran pada prinsipnya adalah sebuah proses komunikasi, yakni proses penyampaian pesan yang diciptakan melalui suatu kegiatan penyampaian dan tukar menukar pesan atau informasi oleh setiap guru dan peserta didik. Pesan atau informasi dapat berupa pengetahuan, keahlian, ide, pengalaman dan sebagainya.

Melalui proses komunikasi, pesan, atau informasi dapat diserap dan dihayati orang lain. Supaya tidak terjadi miss dalam proses komunikasi perlu digunakan sarana yang dapat membantu proses komunikasi yang disebut media. Dalam proses belajar mengajar, media digunakan untuk memperlancar arus komunikasi belajar mengajar yang popular disebut media pembelajaran.

Media pada dasarnya adalah suatu pesan.Implikasinya adalah Sangat penting untuk memahami media apa yang terbaik untuk menyampaikan pesan. Individu pada dasarnya memanfaatkan/menggunakan media untuk memuaskan kebutuhan dan mencapai suatu tujuan. Lundberg \& Hulten(1995) menyebutnya sebagai suaru "uses and gratification model" (model penggunaan dan kepuasan terhadap suatu media), di mana ada lima elemen pada model tersebut, yakni:

(1) Audiens dianggap berperilaku aktif. Mereka menggunakan media berdasarkan tujuan tertentu.

(2) Dalam proses komunikasi massa, sebagian besar inisiatif dalam mengaitkan pemuasan kebutuhan, pencapaian tujuan, dan pemilihan media yang digunakan, tergantung pada audiens. Schramm, Lyle \& Parker(1995) menyatakan suatu terminologi "efek" yang cenderung disalahartikan, karena menganggap televisi "melakukan sesuatu" terhadap anak-anak, padalah faktanya adalah bahwa anak-anaklah yang lebih aktif dalam hubungan antara mereka dengan televisi. Anak-anaklah yang menggunakan televisi dan bukan sebaliknya.

(3) Pada dasarnya, media yang bersaing dengan hal-hal lain yang dapat dijadikan sarana pemuas kebutuhan para audiens. Kebutuhan dasar yang dapat di penuhi oleh media hanyalah sebagian dari kebutuhan dasar manusia yang lebih luas, dan tingkat kepuasan yang didapat dengan mengkonsumsi media juga bervariasi (tidak sama antara seorang individu dengan lainnya).

(4) Secara metodologis, banyak tujuan dari penggunaan media yang didapatkan dari sesama audiens secara individual.

(5) Beberapa studi menunjukkan bahwa kepuasan audiens didapatkan sedikitnya dari tiga sumber yang berbeda dari suatu media, yakni: isi media, eksposure yang ditampilkan media, dan konteks sosial yang menggambarkan situasi dari eksposure terhadap media lain yang 
berbeda.

Setiap media menawarkan suatu kombinasi yang unik seperti: (a) karakteristik isinya; (b) sifatsifat khasnya; dan (c) situasi khusus khasnya. Pemahaman akan kesetaraan media dengan dunia nyata, menjadi suatu pemahaman yang dapat dijadikan dasar dalam membuat atau mendesain media untuk keperluan pembelajaran. Kesetaraan media itu sendiri harus dilihat dari banyak sudut, diantaranya adalah bagaimana suatu gambar direpresentasikan sebagai simbol dari suatu keadaan yang nyata.

Ada dua pendekatan yang digunakan untuk memahami kesetaraan media ini, yaitu menggunakan sifat-sifat (attributes) media sebagai langkah awal studi dengan asumsi bahwa mediamedia yang memiliki kesamaan atribut akan memuaskan kebutuhan-kebutuhan yang sama, dan begitu juga sebaliknya, media yang berbeda atribut akan memuaskan kebutuhan-kebutuhan yang berbeda pula; atau, menggunakan struktur dari audiens sebagai langkah awal studi, dengan anggapan bahwa kebutuhan-kebutuhan yang berkaitan secara psikologis atau kebutuhankebutuhan yang mirip secara konseptual akan dapat dipuaskan oleh media-media yang memiliki kesamaan/kemiripan atribut.

Teknologi pendidikan mengimplikasikan penggunaan alat-alat teknologi yang digunakan sebagai alat bantu mengajar seperti, televisi, radio, maupun film (Wijaya, dkk. 1992). Seringkali peralatan berbasis teknologi dibuat bukan untuk tujuan pendidikan. Tetapi, guru dapat memanfaatkan peralatan tersebut untuk membantu kegiatan pembelajaran, sehingga guru memasukkan alat-alat berbasis teknologi tersebut sebagai bagian dari prosedur pengajaran di kelas.

Seels and Richey (1994) menegaskan bahwa sejalan dengan perkembangan waktu, sekarang ini banyak muncul desainer media pembelajaran berbasis teknologi. Mereka menyarankan bahwa desain untuk membuat media yang mampu memenuhi kebutuhan terhadap individu, kelompok, maupun lingkungan. Media bantu pembelajaran berbasis teknologi telah mengalami perubahan dari yang tadinya berupa visual saja menjadi yang lebih bersifat interaktif.

Kalau kita membahas masalah media tentu ruang lingkupnya sangat luas. Oleh karena itu, di sini masalah media kita batasi ke arah yang relevan dengan masalah pembelajaran. Assosiation of Education and Communication Technology (AECT), yakni sebuah asosiasi yang bergerak di bidang teknologi dan komunikasi di Amerika, membatasi media sebagai segala bentuk dan saluran yang digunakan orang untuk menyalurkan pesan/ Informasi. Sedangkan Briggs (1970) berpendapat bahwa media adalah segala alat fisik yang dapat menyajikan pesan serta merangsang siswa untuk belajar. Contoh konkretnya adalah: buku, film, dan kaset. Sementara, menurut Asosiasi Pendidikan Nasional (National Education Assosiation), media adalah bentuk-bentuk komunikasi tercetak maupun audiovisual serta peralatannya. Media hendaknya dapat dimanipulasi, dilihat, didengar, dan dibaca. Apapun batasannya, masalah media ini mempunyai persamaan bahwa media adalah segala sesuatu yang dapat digunakan untuk menyalurkan pesan dari komunikator ke komunikan, sehingga dapat merangsang pikiran, perasaan, dan minat serta perhatian siswa sedemikian rupa, sehingga proses belajar terjadi.

Media pembelajaran yang baik akan mengaktifkan pembelajar dalam memberikan tanggapan, umpan balik dan juga mendorong yang dididik untuk melakukan praktek-praktek yang benar. Ada beberapa kriteria untuk menilai keefektifan sebuah media, dan menurut Hubbard (1983) ada 9 (sembilan) kriteria, yakni:

(1) Biaya

(2) Fasilitas pendukung

(3) Kecocokan dengan ukuran kelas

(4) Keringkasan

(5) Kemampuan untuk diubah

(6) Waktu dan tenaga penyiapan

(7) Pengaruh yang ditimbulkan

(8) Kerumitan

(9) Kegunaan

Kriteria di atas untuk media konvensional, sedangkan untuk media multimedia, menurut 
Thorn (1995), ada 6 (enam) kriteria, yakni:

(1) Kemudahan navigasi

(2) Kandungan kognisi

(3) Pengetahuan

(4) Presentasi Informasi

(5) Integrasi media

(6) Fungsi

Sedangkan media pembelajaran yang berkembang pada era milenium ini ada dua, yaitu:

(1) Komputer

Pemanfaatan jaringan komputer untuk pembelajaran interaktif, media ini sangat berguna untuk sistem pendidikan jarak jauh yang dikenal dengan computer conferencing system (CCS).

(2) Internet

Internet sangat berguna untuk media pembelajaran, terutama di negara-negara maju, fakta berbicara bahwa media ini sangat efektif dalam proses belajar mengajar baik untuk jarak dekat maupun jarak jauh. Hal itu karena sifat dan karakteristik internet yang sangat khas, sehingga bisa digunakan sebagai media pembelajaran sebagaimana media lain yang telah digunakan sebelumnya seperti radio, tv, CD-ROM, dan lain-lain.

\subsection{Media Pembelajaran sebagai Pembawa Pesan}

Pada dasarnya media hanya sebagai alat bantu mengajar para guru (teaching aids), alat bantu yang dipakai adalah alat bantu visual seperti gambar, model, objek, dan sebagainya, yang dapat memberikan pengalaman konkret, motivasi belajar serta mempertinggi retensi belajar siswa. Dengan masuknya pengaruh teknologi di abad ke-20, alat visual dilengkapi dengan digunakannya alat audio yakni audiovisual aids (AVA). Adapun peralatannya sangat beragam yang dapat digunakan guru menyampaikan pesan ajaran kepada siswa melalui penglihatan dan pendengaran untuk menghindari verbalisme yang masih mungkin terjadi kalau hanya digunakan alat bantu visualnya saja.

Pada akhir 1950, ada pergeseran teori dalam proses belajar mengajar, yakni pengaruh teori komunikasi yang memengaruhi penggunaan alat bantu audiovisual, sehingga selain sebagai alat bantu media juga berfungsi sebagai penyalur pesan dan informasi belajar. Kemudian, behaviorism theory pada 1960-1965, yang diajarkan BF. Skinner ikut memengaruhi pengguaan media pembelajaran. Teori ini mendorong orang untuk lebih memperhatikan siswa dalam proses belajar mengajar. Menurut teori ini, mendidik adalah mengubah tingkah laku siswa.

Pengaruh-pengaruh terus berkembang, yakni pada 1965 - 1970, giliran pendekatan sistem (system approach) mulai menampakkan pengaruhnya. Pendekatan system ini mendorong digunakannya media sebagai bagian integral dalam program pembelajaran. Program pembelajaran direncanakan berdasarkan kebutuhan dan karakteristik siswa serta diarahkan kepada perubahan tingkah laku siswa sesuai dengan tujuan yang ingin dicapai. Guru-guru mulai saat itu merumuskan tujuan pembelajaran berdasarkan tingkah laku siswa. Dari sini lahirlah konsep penggunaan multimedia dalam kegiatan pembelajaran.

Ada beberapa faktor yang menjadi penghambat/penghalang proses komunikasi di kelas, yakni:

(1) Hambatan psikologis, yakni minat, sikap, pendapat, kepercayaan, intelegensi, pengetahuan. Siswa yang senang terhadap mata pelajaran, topik serta gurunya tentu lain hasil belajarnya dibandingkan dengan yang tidak respek.

(2) Hambatan fisik, yakni seperti kelelahan, sakit, keterbatasan daya indera, dan cacat tubuh. Oleh karena itu, kita jangan terlalu banyak mengharap dari siswa yang sedang sakit, karena pesan-pesan yang diberikan akan terhambat, atau siswa sehat sekalipun untuk mengamati kehidupan binatang satu sel dengan mata telanjang.

(3) Hambatan kultur, yakni seperti perbedaan adat istiadat, norma-norma sosial, kepercayaan, dan nilai-nilai panutan. Perbedaan adat istiadat, norma sosial dan kepercayaan kadang-kadang bisa menjadi sumber salah paham. 
(4) Hambatan lingkungan, yakni hambatan yang ditimbulkan situasi dan kondisi keadaan sekitar. Proses belajar mengajar di tempat yang tenang, sejuk, dan nyaman, tentu akan lain dengan proses yang dilakukan di kelas yang bising, panas, dan berjubel.

Oleh karena adanya berbagai jenis hambatan tersebut, baik dari dalam diri guru maupun siswa, baik sewaktu meng-encode (proses penuangan pesan kedalam simbol-simbol komunikasi) pesan maupun men-decode-nya (proses penafsiran simbol-simbol komunikasi yang mengandung pesan-pesan), proses komunikasi belajar mengajar sering berlangsung tidak efektif dan efisien. Oleh karenanya, melalui media pembelajaran dapat menjadi salah satu sumber belajar yang dapat menyalurkan pesan, sehingga dapat membantu mengatasi hal tersebut.

\subsection{Kegunaan Media Pembelajaran}

Secara umum, kegunaan media pembelajaran dalam proses belajar mengajar adalah sebagai berikut:

(1) Memperjelas penyajian pesan agar tidak bersifat verbalisme, baik dalam bentuk katakata tertulis atau lisan.

(2) Mengatasi keterbatasan ruang, waktu dan daya indera sebagai:

(a) Objek yang terlalu besar - bisa digantikan dengan realita, gambar, film bingkai, film atau model.

(b) Objek yang kecil- dibantu dengan proyektor mikro, film bingkai, film atau gambar

(c) Gerak yang terlalu lambat atau cepat, dapat dibantu dengan timelapse atau highspeed photography)

(d) Kejadian atau peristiwa yang terdapat di masa lalu bisa ditampilkan lagi lewat rekaman fim, video, film bingkai, foto, maupun secara verbal.

(e) Objek terlalu kompleks (mesin-mesin) dapat disajikan dengan model, diagram, dan lain-lain.

(f) Konsep terlalu luas (gunung berapi, gempa bumi, iklim dll) dapati disajikan dengan model, diagram dan lain-lain.

(3) Dengan menggunakan media pembelajaran secara tepat dan bervariasi maka sikap pasif peserta didik dapat diatasi. Dalam hal ini media pembelajaran berguna untuk:

(a) Menimbulkan kegairahan belajar

(b) Memungkinkan interaksi yang lebih langsung antara siswa dengan lingkungan dan kenyataan.

(c) Memungkinkan siswa belajar sendirisendiri menurut kemampuan dan minatnya.

(4) Dengan sifat yang unik pada setiap siswa, ditambah lagi dengan lingkungan yang berbeda, sedangkan kurikulum dan materi pendidikan ditentukan sama untuk setiap siswa, maka guru akan banyak mengalami kesulitan bilamana semuanya harus diatasi sendiri. Apalagi latar belakang lingkungan guru dengan siswa juga berbeda. Masalah ini dapat diatasi dengan media pembelajaran yaitu:

(a) Memberikan perangsang yang sama

(b) Mempersamakan pengalaman

(c) Menimbulkan persepsi yang sama

Untuk itu dalam proses belajar mengajar agar efektif, efisien, dan berkualitas, idealnya perlu memperhatikan media pembelajaran. Selain itu, media pembelajaran juga memiliki nilai praktis dan kegunaan yang amat besar dalam proses belajar mengajar.

\subsection{Media Audio Visual}

Media pendidikan erat kaitannya dengan pemberdayaan teknologi dalam pendidikan, dan teknologi pendidikan. Dalam studi teknologi pendidikan, ada perbedaan gradual antara alat audiovisual (audiovisual aids) dan media audiovisual (audiovisual media). Hills (1982) dalam Hamalik (2002: 18) mengungkapkan sebagai berikut:

Audio Visual Aids (AVA) adalah alat-alat yang menggunakan penginderaan penglihatan dan pendengaran. Suatu pelatihan yang menggunakan alat melalui kedua sensoris untuk menerima input dapat mencapai tingkat efektivitas yang tinggi. 
Alat-alat yang termasuk pada AVA meliputi: Sound film, Filmstrip, tape/slide, siaran televisi, CCTV, dan rekaman video. Perkembangan terakhir ialah mulai dipergunakannya mikroprosessor dalam pembelajaran (multimedia) misalnya pembelajaran berbasis komputer (CAI) dan pelatihan berbasis komputer(CBT).

Media audiovisual pada hakikatnya adalah suatu representasi (penyajian kembali) realitas, terutama melalui penginderaan penglihatan dan pendengaran yang bertujuan untuk mempertunjukkan pengalaman-pengalaman pendidikan yang nyata kepada siswa. Cara ini dianggap lebih tepat, cepat, dan mudah dibandingkan dengan hanya melalui pembicaraan, pemikiran, dan cerita mengenai pengalaman pendidikan.

Dengan demikian, media pendidikan berfungsi ganda, yakni sebagai pembawa atau penyalur pesan/informasi dan sebagai unsur penunjang proses pembelajaran (Hamalik, 2000: 20).

\subsection{Jenis-Jenis Media Audio Visual}

Teknologi dalam pendidikan pada dasarnya mendayagunakan media audio visual elektronik sebagai media komunikasi, untuk menyampaikan pesan-pesan pendidikan kepada para peserta didik. Pendayagunaan media tersebut dapat secara sendiri ataupun kombinasi beberapa media. Keterlibatan pendidik dalam komunikasi bergantung pada jenis media yang digunakan, jenis informasi yang disampaikan; metode komunikasi yang dilaksanakan; pemanfaatan waktu dan tempat secara tepat, serta kemampuan komunikator/ pendidikan yang bersangkutan.

Jenis-jenis media audio visual yang dimaksud adalah sebagai berikut:

(1) Transparansi

Beberapa jenis informasi (bagian-bagian penting) ditulis pada lembaran transparansi tersebut dan disajikan melalui bantuan OHP. Proses komunikasi kepada audiens disertai dengan penjelasan secara lengkap dan menyeluruh.

(2) Slide
Bahan informasi tersusun dalam satu unit yang dibagi-bagi menjadi perangkat slide yang disusun secara sistematis, dan disajikan secara berurutan. Slide satu dengan yang lainnya terlepas-lepas dan tidak bersuara. Bentuk komunikasi ini lebih efektif bila disertai dengan pennjelasan lisan atau dibarengi dengan rekaman yang telah disiapkan untuk menunjang sajian melalui slide tersebut.

(3) Filmstrip

Satuan informasi dalam media ini disajikan secara berkesinambungan, tidak terlepas-lepas, tapi sebagai satu unit bahan yang utuh. Media ini tidak bersuara, dan karenanya perlu dibantu dan dilengkapi dengan penjelasan verbal atau dikombinasikan dengan penjelasan melalui rekaman.

(4) Rekaman

Semua bahan informasi dirancang dan direkam secara lengkap. Audiens mengikuti sajian sebagaimana halnya mengikuti ceramah: mencatat hal-hal yang dianggap perlu, menulis pertanyaan-pertanyaan yang berkaitan dengan hal-hal yang belum jelas. Media ini bersifat satu arah dan dapat digunakan untuk membantu media lainnya, misalnya siaran radio.

(5) Siaran Radio

Program siaran radio dapat dipergunakan dalam rangka pembelajaran jarak jauh. Siaran ini dapat menggunakan rekaman atau komunikator. Si pembicara mengajukan informasi/pembelajaran dalam siaran langsung. Rekaman dan program radio menitikberatkan pada pendayagunaan segi pendengaran ( $a u$ dio), segi visual diabaikan dan komunikasi berlangsung satu arah.

(6) Film

Media film mengkombinasikan media audiovisual dan media audio. Suatu rangkaian cerita yang disajikan dalam bentuk gambar pada layar putih disertai suara dan gerakan-gerakan dari para pelakunya. Keseluruhan bahan informasi disajikan lebih menarik dengan nada dan gaya serta tata warna, sehingga sajiannya lebih merangsang minat dan perhatian penonton 
atau penerima pesan.

(7) Televisi

Program siapan televisi lebih unggul dibandingkan dengan siaran radio dan film, bahkan kedua media tersebut sekaligus digunakan dalam program siaran TV. Wilayah jangkauannya lebih luas, lebih bervariasi dan menarik, dapat dirancang secara khusus atau melalui siaran langsung. Program siaran memuat banyak informasi karena adanya siaran lainnya. Sistem komunikasi berlangsung satu arah, peningkatan efektivitasnya perlu diupayakan dengan bantuan komunikasi langsung.

(8) Video tape atau Video cassete

Media ini hampir sama dengan rekaman (recording), yakni meliputi rekaman gambar. Rekaman diputar ulang dan tampak gambar film yang berkombinasi dengan suara. Media ini hampir sama dengan film biasa, lebih sederhana, dan lebih praktis. Keunggulan yang dimiliki oleh rekaman, radio, film, dan televisi juga dimiliki media ini.

(9) Laboratorium

Pembelajaran melalui laboratorium juga menggunakan rekaman, baik rekaman (suara) maupun rekaman video cassete dalam suasana laboratorio. Antara komunikator dengan audiens dapat berkomunikasi dua arah. Model laboratorio, ahli laboratorium bahasa dan laboratorium pengajaran mikro.

(10) Komputer

Penggunaan komputer dalam komunikasi pembelajaran pada prinsipnya sama dengan computerized instruction atau CAI. Kemampuannya menerima informasi, menyimpan, dan mengolah, serta memproduksinya dalam jumlah yang banyak dan dalam jangka waktu yang sama, serta setiap saat dapat digunakan dan dapat menggandakan informasi dalam jumlah tak terbatas, merupakan suatu media yang sangat canggih. Adapun teknik penggunaannya dalam bentuk:

(a) Belajar mandiri berdasarkan bahan yang telah direkam dalam alat khusus, yang memungkinkan terjadinya komunikasi dua arah antara individu dan komputer.

(b) Menyimpan bahan informasi dalam alat penyimpan pada komputer, yang pada waktu tertentu dapat diungkapkan kembali dan dipelajari.

(c) Belajar bahasa komputer yang memiliki ciri khas.

(d) Belajar dengan bantuan tutor dalam prosedur belajar komputerisasi.

Bentuk-bentuk komunikasi/pembelajaran dengan media elektronik tersebut merupakan alternatif yang dapat dilakukan, Namur masingmasing media memiliki kelemahannya.

\subsection{Internet sebagai Media Pembelajaran}

Penggunaan Internet untuk keperluan pendidikan yang semakin meluas, terutama di negara-negara maju, merupakan fakta yang menunjukkan bahwa dengan media ini memang dimungkinkan diselenggarakannya proses belajar mengajar yang lebih efektif. Hal itu terjadi karena dengan sifat dan karakteristik internet yang cukup khas, sehingga diharapkan bisa digunakan sebagai media pembelajaran sebagaimana media lain telah dipergunakan sebelumnya seperti radio, televisi, CD-ROM interaktif, dan lain-lain.

Sebagai media yang diharapkan akan menjadi bagian dari suatu proses belajar mengajar di sekolah, internet harus mampu memberikan dukungan bagi terselenggaranya proses komunikasi interaktif antara guru dengan siswa sebagaimana yang dipersyaratkan dalam suatu kegiatan pembelajaran. Kondisi yang harus mampu didukung oleh internet tersebut terutama berkaitan dengan strategi pembelajaran yang akan dikembangkan, yang kalau dijabarkan secara sederhana, bisa diartikan sebagai kegiatan komunikasi yang dilakukan untuk mengajak siswa mengerjakan tugas-tugas dan membantu siswa dalam memperoleh pengetahuan yang dibutuhkan dalam rangka mengerjakan tugas-tugas tersebut (Boettcher 1999).

Strategi pembelajaran yang meliputi pengajaran, diskusi, membaca, penugasan, presentasi, dan evaluasi, secara umum 
keterlaksanaannya tergantung dari satu atau lebih dari tiga mode dasar dialog/komunikasi sebagai berikut (Boettcher 1999):

(1) Dialog/komunikasi antara guru dengan siswa

(2) Dialog/komunikasi antara siswa dengan sumber belajar

(3) Dialog/komunikasi di antara siswa Apabila ketiga aspek tersebut bisa diselenggarakan dengan komposisi yang serasi, maka diharapkan akan terjadi proses pembelajaran yang optimal. Para pakar pendidikan menyatakan bahwa keberhasilan pencapaian tujuan dari pembelajaran sangat ditentukan oleh keseimbangan antara ketiga aspek tersebut. (Pelikan, 1992). Kemudian, dinyatakan pula bahwa perancangan suatu pembelajaran dengan mengutamakan keseimbangan antara ketiga dia$\log$ /komunikasi tersebut sangat penting pada lingkungan pembelajaran berbasis Web (Bottcher, 1999).

Yang kemudian menjadi pertanyaan adalah, apakah internet mampu memenuhi ketiga persyaratan tersebut? Sebagaimana telah dibahas secara sepintas di bagian depan, sesungguhnya internet merupakan media yang bersifat multirupa. Pada satu sisi, internet bisa digunakan untuk berkomunikasi secara interpersonal, misalnya dengan menggunakan e-mail dan chat sebagai sarana berkomunikasi antarpribadi (one to one communications); di sisi lain, dengan e-mail, pun pengguna bisa melakukan komunikasi dengan lebih dari satu orang atau sekelompok pengguna yang lain (one to many communications). Bahkan, sebagaimana telah disinggung di bagian depan, internet juga memiliki kemampuan memfasilitasi kegiatan diskusi dan kolaborasi oleh sekelompok orang. Di samping itu, dengan kemampuannya untuk menyelenggarakan komunikasi tatap muka (teleconference), memungkinkan penngguna internet bisa berkomunikasi secara audiovisual, sehingga dimungkinkan terselenggaranya komunikasi verbal maupun nonverbal secara real time.

Dengan demikian terlihat bahwa secara nyata internet memang akan bisa digunakan dalam setting pembelajaran di sekolah, karena memiliki karakteristik yang khas, yaitu: (1) sebagai media interpersonal dan juga sebagai media massa yang memungkinkan terjadinya komunikasi one to one maupun one to many; (2) memiliki sifat interaktif; dan (3) memungkinkan terjadinya komunikasi secara sinkron (syncronous) dan maupun tertunda (asyncronous), sehingga memungkinkan terselenggaranya ketiga jenis dialog/komunikasi yang merupakan syarat terselenggaranya suatu proses belajar mengajar.

\subsubsection{Kondisi yang Diperlukan}

Sebagai dasar untuk memanfaatkan internet sebagai media pembelajaran dalam setting sekolah, ada beberapa hal yang perlu mendapat perhatian dan penanganan yang serius agar pennyelenggaraan pemanfaatan internet untuk pembelajaran bisa berhasil, yaitu:

(1) Faktor lingkungan, yang meliputi institusi penyelenggara pendidikan dan masyarakat.

(2) Siswa atau peserta didik meliputi usia, latar belakang, budaya, penguasaan bahasa dan berbagai gaya belajarnya.

(3) Guru atau pendidik meliputi latar belakang, usia, gaya mengajar, pengalaman, dan personalitinya.

(4) Faktor teknologi meliputi komputer, perangkat lunak, jaringan, koneksi ke internet, dan berbagai kemampuan yang dibutuhkan yang berkaitan dengan penerapan internet di lingkungan sekolah.

\subsubsection{Institusi}

Peranan institusi yang diwujudkan dalam bentuk kebijakan dan komitmen, sangat menentukan terselenggaranya pemanfaatan internet untuk pendidikan dalam lingkungan sekolah. Institusi yang paling pertama, yang dituntut untuk memiliki komitmen dalam pendayagunaan internet untuk pembelajaran tentu saja adalah sekolah. Hal ini terutama berkaitan dengan penggunaan teknologi tinggi yang menyangkut keharusan menyediakan sejumlah dana untuk penyediaan peralatan (komputer dan kelengkapannya), jaringan, line telepon (koneksi ke ISP), biaya berlangganan ke internet service 
provider (ISP), biaya penggunaan telepon, dan sebagainya.

Kesulitan tidak hanya untuk investasi peralatan ataupun infrastrukturnya, tetapi juga pada masalah biaya perawatan dan biaya operasional, yang harus dikeluarkan agar sistem terus bisa berfungsi. Belum lagi kesulitan untuk menyiapkan sumber daya manusia yang memiliki kompetensi untuk mengelola sistem, baik sistem pembelajaran melalui internet maupun sistem pengelolaan fasilitas (perangkat keras, jaringan dan sofware management). Peranan institusi lain yang tidak kalah pentingnya ialah dalam memberikan kesadaran, baik terhadap guru maupun siswa tentang teknologi komunikasi dan informasi terutama potensi internet sebagai media pembelajaran.

Kemudian, dilanjutkan pemberian pengetahuan mengenai prosedur dan tatacara memanfaatkan internet, melalui berbagai kegiatan dan pelatihan yang terus menerus, sehingga secara tidak langsung akan tercipta lingkungan yang akrab teknologi. Dengan demikian, terlihat bahwa hal yang paling mendasar dalam penerapan internet di sekolah adalah tekad, kesiapan, dan kesungguhan institusi yang diwujudkan dengan suatu kebijakan yang menyeluruh, meliputi kebijakan berubahnya metode pengajaran, kebijakan mengenai manajemen dan prosedur, kebijakan mengakses internet dan lain-lain. Karena semua itu merupakan kunci utama keberhasilah pendayagunaan internet untuk pembelajaran di lingkungan sekolah.

\subsubsection{Masyarakat}

Lingkungan yang perlu mendapat perhatian ialah lingkungan keluarga siswa. Karena dari lingkungan keluargalah diharapkan munculnya dukungan yang mampu memberikan dorongan untuk memotivasi siswa dalam memanfaatkan internet untuk keperluan pendidikan. Hardjito (2001) dalam penelitiannya terhadap 210 siswa SMU dan SMK di DKI Jakarta yang secara rutin mengakses internet, menemukan bahwa siswa yang rajin mengakses internet sebagian besar $(55,7 \%)$ datang dari lingkungan keluarga yang semua anggotanya (orang tua, kakak/adik) menggunakan internet, dan hanya $5,7 \%$ dari keluarga yang sama sekali tidak menggunakan internet. Kemudian, selain keluarga, lingkungan paling dekat lainnya yang sangat mempengaruhi siswa dalam menggunakan internet ialah teman sebaya (peer group).

Pengaruh lingkungan ini bahkan lebih besar dari lingkungan keluarga, sebagaimana didapatkan dari hasil penelitian Hardjito (2001) yang menunjukkan bahwa dari temanlah mereka pertama kali belajar internet, mengajari internet secara lebih mendalam dan mendapatkan dorongan untuk menggunakan internet. Oleh karena itu, lingkungan siswa ini juga dipersiapkan dan disentuh agar tercipta suasana yang kondusif, yang mampu memberikan dukungan terhadap siswa dalam memanfaatkan internet untuk pendidikan.

\subsubsection{Guru}

Peranan guru tak kalah menentukannya terhadap keberhasilan pemanfaatan internet di sekolah. Dari berbagai pengalaman, menunjukkan bahwa inisiatif pemanfaatan internet di sekolah justru banyak yang datang dari guru-guru yang memiliki kesadaran lebih awal tentang potensi internet guna menunjang proses belajar mengajar. Keberhasilan pembelajaran berbasis internet ini secara signifikan ditentukan oleh karakteristik guruguru yang akan dilibatkan dalam pemanfaatan internet. Untuk itu, perlu diperhatikan hal-hal sebagai berikut:

(1) Guru perlu diberikan pemahaman berbagai keuntungan, termasuk kelebihan dan kelemahan penggunaan internet untuk pembelajaran, sehingga mereka memiliki motivasi dan komitmen yang cukup tinggi.

(2) Guru, baik nantinya dia akan berperan sebagai pengembang dan pengguna maupun yang diproyeksikan sebagai pengelola sistem pembelajaran berbasis internet, harus dibekali dengan kesadaran, wawasan, pengetahuan, dan keterampilan tentang internet.

(3) Guru yang akan dilibatkan dalam pengembangan dan pemanfaatan internet untuk pembelajaran hendaknya memiliki 
pengalaman dan kemampuan mengajar yang cukup.

(4) Jumlah guru yang akan dilibatkan dalam pengembangan dan pemanfaatan internet untuk pembelajaran, hendaknya disesuaikan dengan kebutuhan dan dilakukan secara bertahap.

(5) Guru harus memiliki komitmen dan keseriusan dalam menangani pengembangan dan pemanfaatan internet untuk pembelajaran.

(6) Tetap menjaga gaya mengajar tiap-tiap guru, karena hal itu akan dicerminkan dalam cara pembelajaran mereka kelak di sistem pembelajaran dengan internet.

\subsubsection{Siswa}

Pemahaman tentang audiens bisa didapat melalui analisis dengan menggunakan data demografi maupun psikografi, antara lain, dengan menguji perbedaan-perbedaan karakteristik, sikap dan perilaku audiens. Pemilahan atau pengelompokan diperlukan dalam kaitannya untuk bisa membuat suatu pendekatan atau strategi pendayagunaan internet lebih tepat sasaran, mengingat bahwa sasaran didik tersegmen dalam kelompok sekolah-sekolah yang berbeda. Pemahaman tentang perbedaan-perbedaan motif penggunaan internet berdasarkan aspek demografi dan psikografi tersebut, menjadi penting agar pengembangan program pendidikan dengan mendyaagunakan internet bisa lebih menyentuh kondisi riil sasaran.

Kalau kita mau jujur, sesungguhnya sasaran didik terkelompok dalam segmen-segmen tertentu yang menghendaki adanya perlakuan yang berbeda pula. Sehingga dalam menerapkan pendayagunaan internet di sekolah akan lebih baik apabila melakukan segmentasi secara lebih homogen baik ditinjau dari aspek demografi maupun psikografi.

Walaupun sesungguhnya pendekatan segmentasi ini lebih dikenal dalam konsep pemasaran yang menghendaki diketahuinya kelompok-kelompok sasaran dengan jelas melalui pendekatan segmentasi pasar, namun pendekatan ini sesungguhnya juga bisa diterapkan dalam semua bidang kegiatan termasuk dalam bidang pendidikan. Konsep ini mulai berkembang setelah Wendell Smith (1956) menjelaskan bahwa konsumen pada dasarnya berbeda, sehingga dibutuhkan program-program pemasaran yang berbeda-beda pula untuk menjangkaunya. Pendapat tersebut kemudian diperkuat oleh Frederick Winter (1977) yang menyatakan bahwa konsep average consumer untuk kepentingan praktis - sudah harus dihapuskan dari kamus manajemen pemasaran (Kasali, 1999). Segmentasi adalah hal yang wajib ditempuh dalam suatu proses pemasaran baik komersial maupun sosial, karena dengan demikian kita bisa memberikan pelayanan sebaik-baiknya pada masing-masing segmen dan memberikan kepuasan orang-orang di dalam segmen tersebut (Kasali, 1999).

Hal tersebut juga sejalan dengan teori teknologi pembelajaran di mana keberhasilan tujuan pembelajaran sangat ditentukan oleh sejauh mana kita mengenali sasaran ddik kita. Bila pendidik menganggap siswa mereka sebagai manusia $(h u-$ man being), dengan segala hak-hak dan perbedaan-perbedaan motivasinya, maka ia akan menganggap bahwa murid adalah merupakan bagian atau subyek dari suatu proses belajar mengajar (Heinich, 1996).

Segmentasi menjadi sangat penting, karena sebagaimana yang disampaikan oleh Renald Kasali (1999) dalam bukunya Membidik Pasar Indonesia, Segmentasi Targeting dan Positioning, lebih dari $60 \%$ kegagalan bisnis disebabkan oleh gagalnya pengusaha mendefinisikan pasar yang dituju dan lebih dari $60 \%$ kegagalan kampanye sosial dan politik disebabkan tidak dipahaminya segmen pasar yang dituju.

Dengan mengacu pada hal-hal tersebut, maka sistem pembelajaran dengan mendayagunakan internet yang akan dikembangkan hendaknya memperhatikan adanya perbedaan-perbedaan karakteristik dan segmen sasaran didik. Atau dengan kata lain, perlu dikembangkan suatu sistem pembelajaran yang paling sesua dengan segmensegmen sasaran didik yang dibidik. 


\subsubsection{Teknologi}

Untuk terselenggaranya karena kegiatan pembelajaran dengan dukungan internet, maka setelah ketiga unsur di depan dipenuhi dengan kondisi sebagaimana telah diuraikan, maka faktor teknologi merupakan suatu hal yang juga mutlak harus tersedia dan harus memenuhi standar minimal yang dipersyaratkan, baik yang berkaitan dengan peralatan, infrastruktur, pengoperasian dan perawatannya.

Idealnya, dalam pemanfaatan internet untuk pembelajaran di sekolah, harus tersedia sejumlah komputer yang bisa mengakses internet. Akan lebih baik lagi kalau komputr-komputer yang tersambung ke internet tersebut diletakkan di ruang khusus seperti ruang lab komputer ataupun di ruangan-ruangan lain yang dianggap strategis. Hal tersebut dimaksudkan untuk memberikan kemudahan bagi guru dan siswa dalam mengakses internet.

Cara yang paling efektif dan efisien untuk menghubungkan sejumlah komputer ke internet adalah dengan membangun jaringan lokal (Local Area Network/LAN). Dengan adanya jaringan maka hanya diperlukan satu sambungan saja ke internet yang bisa dipergunakan secara bersamasama oleh komputer yang tergabung dalam jaringan tersebut. Satu hal yang paling penting dari jaringan dan koneksi ke internet untuk keperluan pembelajaran, ialah keandalannya agar bisa dipergunakan setiap saat selama 24 jam dengan tingkat gangguan ataupun kegagalan yang sangat minimal.

Jaringan yang umum dipergunakan ialah model jaringan client/server. Model ini memisahkan secara jelas, komputer mana yang memberikan layanan (server) dan komputerkomputer mana yang mendapat layanan (client). Agar server dan client bisa berkomunikasi diperlukan server program/software dan client program/software. Dari sisi cara menghubungkan server dengan client, ada tiga pilihan topologi yang bisa digunakan, yaitu topologi Bus, topologi Ring, dan topologi Star atau Hub. Sedangkan untuk mengembangkan, mengoperasikan dan merawat infrastruktur tersebut perlu diperhatikan empat aspek dari faktor teknologi, yaitu client (software dan hardware), server (software dan hardware), mode distribusi dan dukungan teknik (McCormack, 1998).

\section{Kesimpulan}

Seringkali kita memilih teknologi ataupun media audiovisual yang akan dipergunakan untuk keperluan proses pembelajaran tanpa bertanya kepada diri sendiri, cara terbaik yang manakah untuk mengomunikasikannya kepada peserta didik kita. Sebenarnya, variasi media audio visual merupakan salah satu pilihan yang kita miliki untuk mengantisipasi berbagai macam perbedaan gaya kognitif peserta didik kita. Masing-masing cara tentu saja memiliki kelebihan dan kekurangan. Misalnya, kita ambil salah satu contoh, pengembangan program pembelajaran dengan menggunakan fasilitas internet mempunyai kelebihan biayanya sangat murah dibanding yang lain, namun memiliki kekurangan, yaitu lebih sulit mengelolanya karena sifatnya yang tidak terintegrasi. Sedangkan dengan menggunakan Web-Course Tools atau pengembangan secara Tailor made biayanya jauh lebih mahal, namun memiliki keuntungan mudah dalam pengembangan dan pengelolaannya, lebih power full, dan sesuai dengan kebutuhan.

Cara mana yang akan dipilih, tentunya kembali kepada pertimbangan berdasarkan kajian terhadap berbagai hal seperti yang telah dibahas di bagian depan. Namun pada dasarnya mendayagunakan berbagai macam media (audiovisual, internet) untuk mendukung peningkatan kualitas pendidikan adalah hal yang sangat dignifikan untuk segera dilaksanakan secara luas di institusi-institusi penyelenggara pendidikan di Indonesia. 


\section{Daftar Pustaka}

Boettcher, Judith V. 1999. Faculty Guide for Moving Teaching and Learning to the Web. USA: League for Innovation in the Community College.

Hamalik, Oemar. 2000. Teknologi Dalam Pendidikan. Bandung: Yayasan Partisipasi Pembangunan Indonesia. Biro penulisan buku.

Hardjito. 2001. "Pola Hubungan Faktor-Faktor yang Mempengaruhi Pemanfaatan Internet: Studi Survai Motif Pemanfaatan Internet Siswa SMU dan SMK DKI Jakarta.” Jakarta: Program Pasca Sarjana, Universitas Indonesia.

Heinich, Robert. 1996. Instructional Media and Technologies for Learning. New Jersey: Prentice Hall, Inc.
Kasali, Rhenald. 1999. Membidik Pasar Indonesia, Segmentasi, Targeting dan Positioning. Cetakan Ketiga. Jakarta: Gramedia Pustaka Utama.

McCormack, Colin. 1998. Building a Web-Based Education System. Canada: Willey Computer Publishing.

Suparman, Atwi, dkk. 1999a. Teknologi Pendidikan: Hakikat Desain, Media dan Strategi Penyampaian. Dalam Pannen, dkk (eds). Cakrawala Pendidikan.

Suparman, Atwi, dkk. 1999b. Teknologi Pendidikan: Difusi \& Implementasi, Manajemen, Evaluasi dan Aplikasi di Berbagai Sektor. Dalam Pannen dkk (eds). Cakrawala Pendidikan. 
